\title{
PIÉLAGOS DE VOZ: SOBRE LA POESÍA DE DOMINGUEZ CAMARGO
}

Desde su revelación merced a Gerardo Diego y gracias a los rigurosos estudios de Emilio Carilla y Giovanni Meo Zilio, la poesía de Hernando Domínguez Camargo ha logrado vencer un olvido injusto que oscureció su genio y empobreció las letras hispánicas '. Preclaro hijo de Góngora, su voz ya no se confunde con los ecos; pero habiéndosele reconocido por fin la autenticidad y la altura, aún queda mucho por decir de su indudable peculiaridad. Tomando el conjunto de la obra del gran santafereño, aunque atendiendo particularmente a su monumental e inconcluso Poema Heroico, trataré de hacer notar lo que a mi juicio constituye una constante - en la cual hasta ahora no ha parado mientes la crítica- que recurre en sus versos con obsesiva insistencia. En efecto, sea en símil, en metáfora, en concepto metamórfico, tal constante pareciera ser el tropos más profundo de la poesía de Domínguez Camargo.

El romance «A un salto por donde se despeña el arroyo de Chillo», acaso su obra más conocida por lo antologizada, se abre con una metáfora sencilla:

1 Gerardo DiBgo, Antología poética en honor a Góngora desde Lope de Vega a Rubén Dario (Madrid, 1927), donde Diego auténticamente descubre a Domínguez Camargo para las letras hispánicas, y su más tardío y lúcido estudio «La poesfa de Domínguez Camargo en nuevas vísperas», Thesaurus, VI (1961), núm. 2, 283-310. Exilio Carilla, El gongorismo en América (Buenos Aires, 1946), págs. 110-134, y Hernando Dominguez Camargo. Estudio y selección (Buenos Aires, 1968). Grovaswi Mso Zilio, Estudios sobre Hernando Dominguez Camargo y su S. Ignacio de Loyola, Poema Heroyco (Messina-Firenze, 1967). 


\section{Corre arrogante un arroyo por entre peñas y riscos, que, enjaezado de perlas, es un potro cristalino ${ }^{2}$.}

La imaginación que ha visto un caballo en el arroyo lo irá aderezando verso a verso hasta vestirlo de auténtica opulencia metafórica. Enjaezada el agua se animaliza, y entonces puede ser descrita como una bestia en su apariencia y conducta. Lleva un «pretal de cascabeles", petral y cascabeles que son pura agua sonora, como sonido de agua son los "cisnes de oro y ruiseñores de vidrio». El cuerpo líquido del arroyo se ha vestido desde la metáfora seminal de entidades muy ajenas al cuerpo acuático y que, sin embargo, definen su color y su sonido:

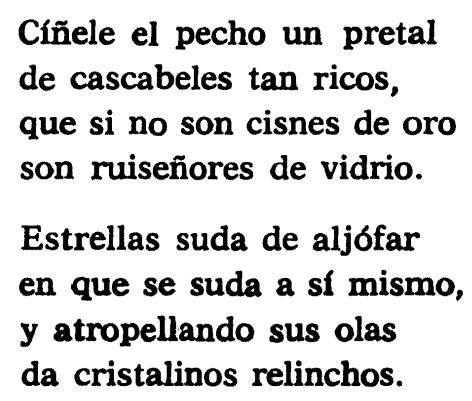

Sólo porque el arroyo es concebido potro puede el agua tener un petral que es de agua, y el petral cascabeles que son el sonido del agua, y los cascabeles llevarnos a las aves, puro canto de agua. El agua, lo informe, se informa de sustancia animal, pero el animal sigue siendo sólo sustancia de agua. En tanto potro suda y relincha como potro, pero suda un sudor que es su misma carne; esas estrellas de perlas su propio cuerpo en espuma, que sonora va hacia el precipicio:

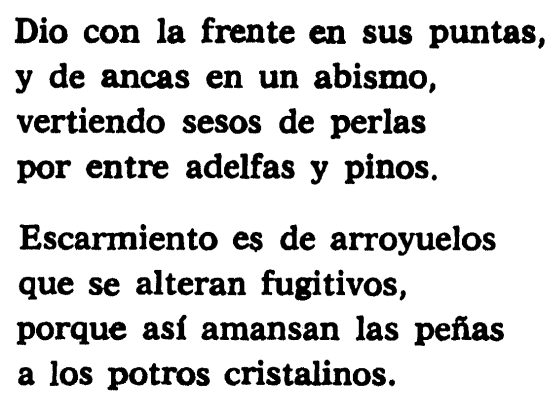

2 Para todas las citas de los poemas de Domínguez Camargo he seguido la edición de Rafael TorRes Quintero, Obras (Bogotá, 1960). El romance aA un salto», páginas 384385. Sobre el romance, ver E. Carilla, «Domínguez Camargo y su Romance al Arroyo del Chillo», Filotogía (Buenos Aires), IX (1963), 37-51. 
Frente, ancas y sesos: todo el mismo cuerpo de agua, porque si el arroyo es potro, este potro sobre todo es arroyo. Sin embargo, el lector ha presenciado, no tanto la caída de un salto de agua, como la muerte de un caballo que desbocado cae al precipicio. El poeta, al transformar el elemento líquido (que no puede morir), en potro enjaezado, relinchante, mortal y muerto lo ha personificado, vivificando lo que no tiene vida, y así ha perpetrado esta breve tragedia lírica. Esa imaginación que hizo del agua carne de bestia, cuero de petral, tejido de jaez, metal de cascabeles, plumas de ruiseñor y cisne, es la misma que a lo largo del resto de su obra transformará toda sustancia en un universo hidrópico y fluyente.

Aún más revelador que el del salto del Chillo es el romance «A la Pasión de Cristo", porque en la descripción metafórica de un arroyo es natural que todo se metamorfosee en realidades líquidas, pero cosa muy diferente es por cierto cuando se trata de un retrato. De este romance conocemos la fuente directa, ya que fue escrito «a imitación de otro [de]... Fr. Hortensio Félix Paravicino», de modo que es muy sencillo averiguar si determinadas características son del poeta o provienen de su fuente.

Domínguez Camargo hace del cuerpo de Cristo, surcado por los azotes, un mar, cuyas orillas son las profundas llagas, rocas sus huesos, nadadora su belleza, sus facciones náufragas:
En las bien surcadas pieles, porque hondas orillas logren, por entre rocas de huesos torrentes purpúreos corren.
Feo hermosamente el rostro, a pesar de los rigores, derrotada beldad nada en náufragas perfecciones 3 .

Los versos correspondientes en el poema de Paravicino, carentes de la metáfora marítima, no podían sugerirle nada semejante.

Más adelante María mira el cuerpo martirizado de su hijo en ambos poemas. En Paravicino la Madre ve los ojos sangrientos, el labio deshecho; y luego en cuatro versos se elabora brevemente una imaginería acuática:

3 «A la Pasión de Cristo», Obras, págs. 394-401. 
Pedazos de alma sangrientos

son, que mueven ambos soles, y Madre de rojas perlas

el labio nácar las coge.

Roca así de bermellón, si no derrumba colores, liquida el golpe de agua resplandecientes tersones 4.

Esta es la única y bien pobre sugestión que pudo hallar Domínguez Camargo en su fuente para una extraordinaria elaboración, más paisajista que retratista, en su pintura del rostro del crucificado: El cabello corre río entre ríos de sangre, se levanta en olas entre las flotantes islas de camelotes, arrecia tormentoso sobre el rostro y finalmente los dos ríos de cabello y sangre inundándose se ahogan el uno al otro. Todo se consuma en un mar de oro y bermellón, sangre y cabellos ya oceánicos:

\begin{abstract}
Nilo es dorado el cabello, porque en rojos maraniones, las avenidas de sangre crecientes de oro arrebolen.

Greñas en la espalda ondean, de oro y carmin chamelotes, crenchas en el rostro baten de sangre y luz tornasoles.

Su descabellado enredo, en dubias inundaciones, si hace el oro que se anegue, hace el carmin que se ahogue.

Anegados en su sangre de los ojos los faroles, entre el golfo del cabello ya aparecen, ya se esconden.

Crece el piélago sus iras $y$ en sus últimos angores en rocas de mermellon 5 hace que su luz zozobre.
\end{abstract}

4 El romance de Paravicino también puede leerse en Obras, págs. 414420. La palabra tersones (pág. 416) es de dudosa lectura: la edición de Bogotá de 1956 interpretó festones; Torres Quintero sugiere tersores.

5 mermellon: bermellon. 
La estructura retórica de este pasaje - y de todos los que veremosresulta superficial comparada a la extraordinaria fuerza sincrética que combina multitud de realidades en una nueva, al transmutar todas las imágenes. Por eso es justo señalar, más que la retórica de la metáfora, la presencia de un profundo tropos. Al licuar cada entidad, la imaginación parece licuarse ella misma, recibiendo y asumiendo la palabra poética en tantas formas de lo proteico por excelencia: el mar. He aqui cómo lágrimas, sangre, piel y nariz forman luego el marítimo paisaje de un rostro humano:

Como el piélago en la orilla

blancos lame caracoles,

Lágrimas y sangre inundan

cruientamente salobres,

en la nariz la eminencia

de una descollada torre.

En esta desolación marítima, batida de olas de sangre y lágrimas, con su solitaria torre devastada, se ve una mujer-roca completando el paisaje. Pongo al lado de los versos del santafereño los correspondientes de Paravicino, para que el lector juzgue hasta qué punto es personal la elaboración de Domínguez Camargo:

Una mujer a su lado, a tanto mar roca inmoble, al piélago de tormentos yunque inflexible se expone

(Dominguez Camargo)
A una mujer se parece que junto al árbol biforme constantemente afligida llama tiernas atenciones.

(Paravicino)

Emilio Carilla ha juzgado que no es peor el romance de Domínguez Camargo que el de Paravicino ${ }^{6}$. Por cierto no es peor, sino muchísimo mejor, tanto en la textura de su retórica como en el meollo de la creación poética. Pero no es aquí cuestión de adjudicar méritos, que hasta sería injusto comparar los logros de un gran poeta, como el americano, a las posibilidades de un versificador ingenioso pero mediocre, como Paravicino, por mucho éxito que tuviera y por muy famoso que fuese. Lo que interesa es perseguir la vaga pauta de la imaginación creadora de Domínguez Camargo, para demostrar palpablemente lo que fuera su intuición esencial.

6 El gongorismo, págs. 120-121.

LXVI, 3.0-4.0. - 7 
El romance prosigue. Cristo muere. El mundo tiembla. Ahora para el poeta el cielo es un «mar de luz», un golfo la tierra, las montañas olas, y hasta el velo que se rasga en el templo es agua entretejida:

\section{Tejido Jordán se rasga \\ y en las orillas que rompe \\ maretas de lino agita, \\ que arca a Cristo reconoce}

En este romance Domínguez Camargo comenzó transformando el cuerpo de Cristo en mar, y terminó por volver el mundo todo en un universo de agua.

Al rastrear esta constante en el Poema Heroico a San Ignacio de Loyola no tomaré en cuenta las muchas y estupendas descripciones del mar, ríos, arroyos, lágrimas y elementos conectados con lo acuático (peces, caracoles...), por no tratarse de construcciones metafóricas. San Ignacio viajó mucho por mar y tierra, de donde su vida ofrecía muy numerosas oportunidades para poetizar lo acuático y marítimo. Tampoco me detendré en las sobradas ocasiones en que mar y aguas recurren en topoi simbólicos, canonizados en la tradición occidental y particularmente en la cristiana.

Desde muy antiguo se concibió el mar como escenario de la vida humana, el mare huius mundi (alegorizado por los exégetas de la Odisea) ${ }^{7}$, heredero del mar real y metafórico del Asno de Oro, con sus Fortunae tempestates, mar tormentoso de la Fortuna que gracias a la enorme influencia de Boecio llegó al medioevo como símbolo en el cual se concentran todos los peligros de la vida humana ${ }^{8}$. El mare huius mundi y mar de la Fortuna se encuentran en el Poema Heroico en elaboraciones del todo tradicionales 9 .

Otro tópico conocido desde Alceo y Horacio es el de la barquilla, que simboliza al hombre en ese mar tempestuoso de la vida, tópico tan venerable como frecuentemente usado durante todo nuestro Siglo de Oro. Barquilla que a veces esconde la venera venusina y resulta así nave del amor. En ambos sentidos aparecen las barquillas de Domínguez

7 Ver F. Bupfitere, Ley Mythes d'Homère et la Pensée Grecque (París, 1956), páginas 374377, y Jzan PÉPIN, Mythe et Allégorie: les Origines Grecques et les Contestations Judéo-Chrétiennes (Paris, 1958), especialmente págs. $99-111$ y 118 y sigs.

8 Para el motivo de la tempestad en Apuleyo, Boecio y la literatura medieval francesa e inglesa, ver la tesis doctoral de Maxwell S. LuRIA, The Christian Tempest: a Symbolic Motif in Medieval Literature (Princeton Univ., 1965).

9 Todas las citas del Poema Heroico se darán en adelante en texto o notas simplemente señalando el Libro correspondiente en mayúscula, y en minúscula la estrofa. Para el mare huius mundi, IV, cxliv; el mar de la Fortuna, IV, clxxxv. 
Camargo, perfectamente fieles a la tradición ${ }^{10}$. Muchos símbolos cristianos conllevan imaginería acuática: la fuente del bautismo (el Jordán bautismal) ${ }^{11}$; San Pedro —santo predilecto de Ignacio- pescador en la navis ecclesiae ${ }^{12}$. Nada de esto es sorprendente. Lo que sí cabe notar es la abundancia y la frecuencia de su uso en la obra de Domínguez Camargo. También es tradicional la alusión al cielo como mar navegado por la nave del sol ${ }^{13}$. Sin embargo, detengámonos un momento en ella, porque en este caso el pasaje tiene un claro subtexto gongorino. Recordando los célebres versos con que Góngora abre sus Soledades, observemos cómo el santafereño transmuta el Toro celeste en sus campos de zafiro (metáfora terráquea), por el $\mathrm{Pez}$ en su piélago sideral:

Era del año la estación nevada
en que, la espina rígido diamante,
brumas la escama lúbrica, argentada
día en onda y onda del zafir brillante,
espumas de astros con la cola alada
o batía o violaba el pez nadante,
no de Neptuno conductor luciente,
de la carroza sí del sol ardiente;
en que, fiscal, en Abrego prendía
erigiendo sus urnas en obscuro
calabozo, las fuentes; y en que el día
atado al banco del invierno duro,
en el remo de un Africo gemía
sulcando el viento, que agitaba impuro
en el seno, que el sol le ilustra breve,
ondas de nubes, piélagos de nieve.

(IV, ccxxxvi)

Ondas de cielo, espumas de estrellas, nave el invierno, galeote el día, el viento mar, las olas nubes, nieves en océano: partiendo de la sugestión de Piscis, Domínguez Camargo ha transmutado todos los elementos del cosmos invernal en un mundo marítimo. Si los jardines del cielo pueden volverse mares, ¿por qué no los vergeles de la tierra? Por eso Domínguez Camargo hace a la abeja «una Sirena / en el ponto del huerto ejecutiva» $(\mathrm{V}$, ciii). Ya que los campos en flor son mares, bien pueden serlo los campos de batalla:

\footnotetext{
10 I, ccxxix; IV, cxliv, clxxxv, ccxlci-ccl.

11 I, xxvii.

$12 \mathrm{I}, \operatorname{ccxxx}$.

13 II, xxvii; IV, lv.
} 
Olas de fuego quiebra en las almenas del ímpetu francés el mar furioso; no menudas del muro lame arenas, escollos sí le muerde proceloso: las armas que tiñeron nobles venas, conchas a su furor son espumoso; y de su mismo corazón armado es roca Ignacio a tanto mar airado.

(I, clxii)

Si en el mar bélico Ignacio es una roca, contra ella se ha de estrellar el torrente no del salto del Chillo sino - ya líquido- del enemigo francés:

Si al cristalino potro, arroyo undoso,

desde el escollo reprimió pendiente

con los que mueve, auriga numeroso,

frenos Orfeo en cítara elocuente:

Loyola, así, del campo temeroso,

desde los muros reprimió el torrente.

(I, cxl)

Es obvio que el subtexto de los primeros versos de esta octava es su propio romance, donde el precipitarse del arroyo, potro cristalino, es contenido por una peña. Aquí un ejército de hombres en armaduras (¿qué podía ser más sólido?) se ha licuado en torrentoso arroyo, detenido en la roca que es Ignacio. Los símiles más corrientes para aludir a lo bélico suelen ser metálicos (bronce, acero) o ígneos (rayos, llamas, relámpagos, incendios). El agua, considerada tradicionalmente un elemento frío, no se prestaba a la comparación. El hecho de que en Domínguez Camargo la comparación no resulte forzada, sino que por el contrario suene justa y espontánea, muestra que la indudable maestría del poeta implica también una entrega, un rendirse a la liquidez. Sus versos están inmersos en la honda seducción de lo fluido. Veamos un caso que claramente invita a un concepto metamórfico no acuático sino telúrico. En los estandartes franceses campeaba por supuesto la flor de lis. ¿Qué hace de ellos nuestro poeta? Pues los mueve bajo sed marina, donde en un mar de viento el pétalo se hace pluma, y bate alas entre salada espuma la flor vuelta marinera:

Hidrópico de viento un estandarte

a un mar de soplos se creyó sediento, y con picada sed su menor parte un golfo se ha bebido en cada aliento; 
ajado un lilio desató sin arte, lisonja tremolada al fácil viento, adonde aleando la vestida espuma, gorza florida fue, o lilio de pluma.

(I, cxci)

El mismo Ignacio se torna ente marino por excelencia, pues vestido con su cota de mallas, «agravado de conchas de diamante... pez escamado pareció nadante» (I, cix). Cuando Ignacio se desnuda de sus vestidos cortesanos para vestir el hábito de su nueva vocación, Domínguez Camargo pinta las ricas prendas en asombroso paisaje:

\author{
Cardada la esmeralda en el vestido, \\ piélago verde el chamelote 14 undoso \\ formaba, de riberas mil ceñido \\ en este y en aquel galón precioso: \\ islas de Ofir los golpes 15 se han fingido; \\ y los botones que caló ingenioso \\ filigranista en cada ojal decoro, \\ torcidos eran filigranas de oro. \\ Roja banda de múrice embriagada \\ si Marańón de púrpura partido \\ en dos raudales, le abrazaba aislada \\ la media espalda y medio pecho, unido \\ después en la bisagra eslabonada \\ de un cerrado botón, si no lucido \\ arco de un ojo de apretada puente \\ en que estrechó el carmín mucha corriente.
}

(II, cii y civ)

Las telas verdes se hacen undosos mares, los galones sus orillas, botones y pasamanería se revelan como islas y caracoles. Las telas carmesíes son ríos, donde un botón une los raudales, rojos de múrice marino. El motivo de la bisagra acaso conlleve algún eco gongorino: «de fugitiva plata / la bisagra, aunque estrecha, abrazadora / de un Océano y otro» (Soledad Primera, 477-474). Sin embargo, en Góngora se trata simplemente de la descripción del estrecho de Magallanes, bisagra de dos cuerpos de agua bien reales. Si Domínguez Camargo recordó en esta oportunidad versos que de todas maneras debía saberse de memoria, lo hizo siguiendo un mecanismo de su imaginación que no podía ser sugerido

\footnotetext{
14 En este caso chamelote no se refiere a la planta ni a las islas que ésta forma como en la referencia anterior, sino al también llamado camelote, tejido fuerte e impermeable, así nombrado porque solía hacerse con pelo de camello (DRAE).

15 golpe: «adorno de pasamaneria sobrepuesto en una prenda de vestir» (DRAE).
} 
por el texto de Góngora. Puesto que para nuestro poeta la banda envolvente es un cuerpo acuático, puede recordar la bisagra del estrecho de Magallanes como metáfora apropiada al botón, que en su mente también une dos raudales.

El tropos metamórfico de lo fluido invade toda realidad en la poesía de Domínguez Camargo. Podría pensarse que ésta es una característica propia del barroco, y en verdad la línea curva y sinuosa, desde el antiguo Egipto jeroglífico mismo del agua, es elemento esencial de la estética barroca. En este sentido la fluidez propiciada por la imaginación del santafereño es parte del mundus significans de sus contemporáneos, revelado con insistencia por todas las artes plásticas de la época. No podía ser de otro modo, porque el significado de toda obra de arte sólo puede hallarse en ese mundus significans, que es su única matriz semiótica. Pero lo propio del edificio verbal de todo gran poeta es lo que hace con ese universo de significantes y significados en que le tocó vivir. Y lo que hace Domínguez Camargo es muy peculiarmente suyo. Como hemos visto, dentro de su poética, esencialmente imitativa, la obsesión por este tropos fundamental no estaba determinada por pre-textos modélicos. El código barroco implicaba lo sinuoso, pero no exigía la invasión del cosmos de significantes por lo acuático, ni la disolución de toda materia en realidades líquidas. El dinamismo de las metáforas de Domínguez Camargo lleva a la fusión de toda entidad en una liquidez que al absorberlo todo, todo lo diluye. $Y$ en este sentido, su poesía resulta una extensión sin precedentes, en el contexto de lo verbal, de la forma rectora en la semiótica de la estética barroca.

Para fundamentar esto aún más concluyentemente voy a enumerar con brevedad una serie de casos más, porque quizá la única manera de probar la existencia de un tropos obsesivo sea la acumulación misma. Hemos visto ya cómo las telas en la poesía del santafereño se metamorfosean en líquidas visiones; veamos ahora cómo una mesa recibe la espuma de sus manteles, y así sus riberas celebran metafórica caza:

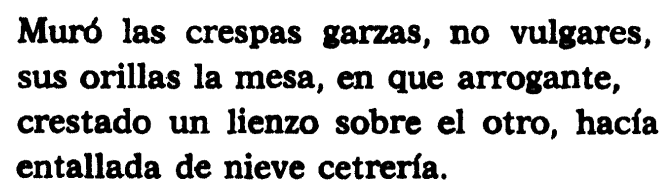

Si la mesa - copa, platos- pueden contener mares y náufragos, de seguro puede guardarlos la cama, mar de amor, golfo de encantadoras sirenas, que el alma escucha nadadora entre la ahalagüeña holanda»: 
Naufragó casi la razón y el tino en el piélago ardiente de una copa, a un cónsul grave aligeraba el vino de los cuidados la pesada ropa: tablas del gusto rotas, roto el lino del sentimiento en la gulosa tropa de escollos no, de platos, daba el pecho a la plumosa playa de su lecho.

En aquel dulce, no, napolitano ponto de Venus sí, en cuyas arenas por el pelo al cariño traen la mano mudamente suaves sus Sirenas, naufragio indujo (bien que soberano) el grito de una voz que en muchas penas zozobra el sueño; y cuando más perdido, el alma sale a nado en el óddo.

(III, cxxxv y cxxxviii)

Puesto que el alma sabe nadar, también a veces navega en un mar de pensamientos, donde remuerden las olas de la conciencia su pobre barquilla rota:

Turban la paz que próspera navega, los siempre fieros y encontrados vientos de escrúpulos, en quien dubia se anega en un amargo mar de pensamientos; y rompido el timón, ciego que entrega a muchas ondas de remordimientos, que quebrando en el alma de Loyola, toda la arrastran en cualquiera ola.

$$
\text { (II, clix) }
$$

Ignacio, para cumplir con eficacia su misión, tiene que estudiar, y así Domínguez Camargo lo convierte - no en un nuevo San Agustín o Santo Tomás, o en algún sabio paladín de mito o leyenda que tome ora la espada, ora la pluma- sino en marino, en nuevo Colón: cada libro una nave de la «literaria flota» para surcar los mares de las letras y descubrir un "Nuevo mundo literario»:

Estas pues, desató de las colunas con que Minerva el literario enfrena piélago, reales naves que, oportunas difícil siempre han inculcado arena: breves hasta su tiempo fueron cunas, que al mar fiaron recatada entena las plumas que, por nueva hoy ya derrota, muchas desatan literaria flota. 
A este Colón se debe el no inculcado piélago hasta allí de antigua pluma, de tanto all cańón divino arado, de tanta hoy docta encanecida espuma.

(IV, ii-iii)

Como sabemos desde Mircea Eliade, todo templo es arquetipo del axis mundi, centro de la tierra. Ha sido la montaña su símbolo más frecuente ${ }^{16}$. Sin embargo, hasta Montserrat, axis mundi por templo y por montaña, es subsumido por esta imaginación oceánica en sus siempre renovados mares. Ignacio es bajel y náufrago, buzo y abeja nadadora; la música y la suntuosidad del templo son a la vez piélagos y tablas de salvación. Hasta las lámparas votivas se ven naves entre las aguas del aire: Coronó los umbrales de la puerta
y embistióle los ojos y el oído la opulencia y la música; y no acierta, de opuestos mar y viento combatido bajel, con rumbo ni derrota cierta; y del mismo naufragio socorrido zozobrando, le ofrece a su grandeza, tabla a la voz y tabla a la riqueza. Inculcando rocios del aurora, el norte cala y sur, en onda y onda, no abeja alada, no, si nadadora, el siempre casto buzo, sin que esconda los granos que en sus ondas atesora, o venera tenaz o gruta honda

Navega, en cuanto espacio se dilata una lámpara y otra suspendida, el culto Potosí en naves de plata el pielago del viento...

$$
\text { (II, lxxii-iii y lxxvii) }
$$

Las personas son también piélagos de gente, diluvios que lo anegan desatados ( $V$, xxxviii y xlii). Cuanto es humano puede hacerse realidad marina: «la nao del corazón, en que la vida / ondas surca de sangren, «los angostos márgenes del pecho» ( $V$, xliii), ya que «es pece el alma que nadar no sabe / sino en los hondos ríos de las venas» (I, ccxxxi). El

16 M. Eliade, Myths, Dreams and Mysteries (New York, 1960), pág. 60, y Patterns in Comparative Religion (Cleveland and New York, 1968), pág. 375: «1-The sacred mountain where heaven and earth meet, stands in the centre of the world; 2-Every temple... is assimilated to a sacred mountain and thus becomes a centre.» 
macrocosmos del mundo - de cielo a tierra, y cuanto ellos abarcanhasta el microcosmos del hombre -desde sus vestidos a su almaambos se consuman con coherencia ejemplar en el tropos acuático. $\mathrm{Hi}$ drópica es palabra especialmente amada por Domínguez Camargo ${ }^{17}$. La palabra, claro está, ya la había usado Góngora, pero nuestro poeta puede como nadie hacerlo con propiedad absoluta. Su palabra es hidrópica, su imaginación lo es, y como los de Segismundo, también debieron serlo sus ojos. Cual dice Ignacio de Loyola bien puede decirse de él: "de su voz y su rostro hidropesía” (II, 1).

Veamos ahora la metamorfosis en la retratística de Domínguez Camargo. Ya hemos observado cómo en el romance "A la Pasión» el poeta transforma la carne de un hombre en ríos y mares metafóricos. Por lo general el encadenamiento de imágenes en su poesía resulta de consistencia magistral; pero alguna rara vez - como llevada la imaginación por lo informe e indiferenciado de sus aguas- las imágenes mismas también naufragan confundidas:

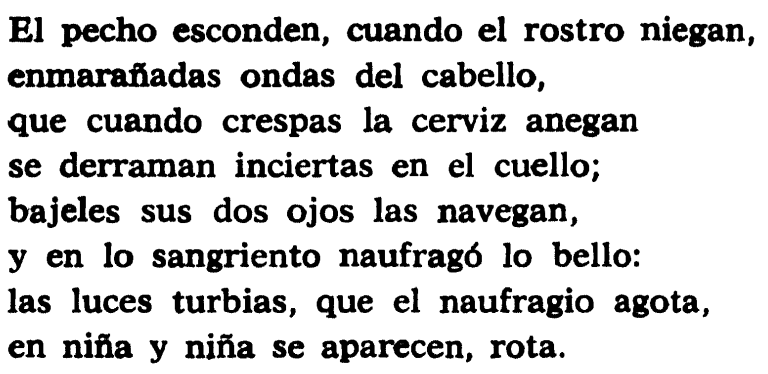

(II, cxxi)

Se trata de otra ekphrasis de Cristo crucificado. Los primeros cuatro versos aluden a la ya conocida inundación por los mares de una cabellera suelta. El problema ocurre en la segunda mitad de la octava, porque los ojos resultan naves, que por cierto han perdido su curso poético, pues parecen estar navegando por las sangrientas crenchas. Con algún esfuerzo podemos imaginar que Domínguez Camargo está visualizando un rostro oculto por el cabello ensangrentado (ya que sus enmaranadas ondas "el rostro niegan"), dejando ver, sin embargo, los ojos mortecinos, como dos barcas rotas. Pero la imagen resulta forzada, porque la movilidad de los ojos (el navegar de los bajeles) depende únicamente de la acción de mirar, y sería inconcebible y hasta degradante pensar que el Dios moribundo se dedicara en su hora suprema a mirarse las propias guedejas, por muy sangrientas que estén. Decía yo que éste es un lapsus muy raro en la poesía de Domínguez Camargo, que parece

17 Meo Zilio, Estudio, pág. 173. 
haber pulido cada verso con precisión admirable. Pero el lapsus mismo es índice de estas imágenes obsesivas que le poblaban el alma. Observemos ahora cómo al recurrir idéntica figura, la palabra poética, en vez de naufragar, navega hacia una nueva conquista. Se trata de otra visión de Cristo, hacia el final del Poema. En ella puede hallarse casi exactamente la misma descripción, pero las metáforas ya no se escapan de sus difíciles cauces:

Entre el peinado golfo del cabello
(que en onda de oro inunda relevada
la blanca frente, y el ebúrneo cuello,
cuando anega la espalda lastimada),
el esplendor de la pupila bello,
en una y otra niña zozobrada,
sirenas dos ostenta, que en canoro
plectro de luz, entonan voces de oro.

(V, cxli)

Domínguez Camargo ha mantenido la unidad del paisaje marítimo, pero afortunadamente eliminó el motivo de los ojos-bajeles de tan lastimosa travesía, para hacerlos ojos-sirenas. El hallazgo verbal es acertadísimo, aunque la metáfora resulta curiosamente compleja por el número de términos en comparación implícita. Los ojos tienen niñas, es decir, doncellas, que por estar en un mar son doncellas marinas, y por hallarse en un golfo (como el de Nápoles) son sirenas. Puesto que la belleza de Cristo, como dice en la octava siguiente, es «parleramente muda las niñas merecen ser sirenas por lo esplendorosas y expresivas: con propiedad plectros de luz y voces de oro. Ambos retratos de Jesús son muy semejantes en su estructura temática, y en la disposición de sus elementos dentro de la estrofa, minuciosamente escindida en cada caso por su justa mitad entre cabellos y ojos. Pero este rostro visto como una marina, donde se pinta un radiante golfo de sirenas resulta, a diferencia del anterior, un auténtico triunfo de coherencia metafórica. La capacidad de la imaginación poética no deja de ser notable en ambos casos, puesto que el gran salto al vacío es el concebir la inaudita posibilidad de describir el rostro humano como un mar, sea surcado ya de barcas, ya de sirenas. Dentro de toda la tradición de una poética que es necesariamente la de la imitatio humanista poco o nada le ofrecía asidero para la sorprendente visión de su retrato. En efecto, dentro de la tradición petrarquista, el rostro blanco y rosa suele ser campo de flores, o suntuosa joyería de plata, rubíes, oro y esmeraldas. El cabello crespo dio, sí, sobrada ocasión para eróticas navegaciones de peines y deseos, pero nada hace esperar esta completa metamorfosis de la carne 
humana en paisaje marítimo. La estrofa que inmediatamente precede la descripción del rostro anuncia la asombrosa imagen:

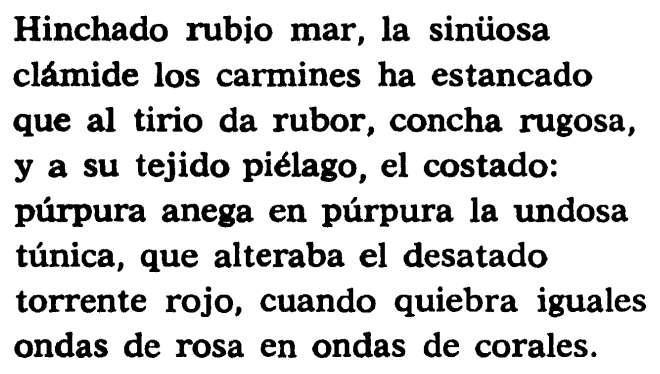

El manto amarillo se curva en dinamismo barroco, mar de sinuosas olas que, ensangrentado por la herida de la lanza en el costado de Cristo, es púrpura, y así múrice, y por lo tanto concha marina. De todo lo cual resulta la apretada ecuación poética de un manto que es un caracol que encierra mares, o se hincha en mares, y por lo tanto es mar. La túnica roja continúa la doble imagen de la púrpura y las ondas. En fin, que si el rostro de Jesús es un golfo de sirenas, su cuerpo está vestido de atejido piélago». Decía que el poeta ha planteado una compleja ecuación poética, ecuación de igualdad por supuesto, que implica un proceso que no tiene, que yo sepa, denominación retórica alguna. Se trata de fusión de realidades, de modo que los límites de cada una quedan anulados, y cada cosa y sustancia pierde su individualidad y diferencia, aniquilándose el ser de todas. El proceso retórico puede tomar muchas formas: metáfora, símil, perífrasis, personificación, metonimia, o cualquier otra figura, pero su alcance no se agota en ninguna de ellas. La más frecuente es por supuesto la metáfora, pero por sí sola no logra definir la fuerza de este fenómeno de esencial conflación - conflactioque fusiona toda realidad, para fundirla en una sustancia última.

Decía que había muy poco en la tradición poética para semejante consumación oceánica. Góngora ofrece en el Polifemo un caso al que se podría acudir como modelo, pues no tuvo Góngora hijo más fiel que nuestro poeta:

Negro el cabello, imitador undoso de las obscuras aguas del Leteo, al viento que los peina proceloso vuela sin orden, pende sin aseo; un torrente es su barba, impetuöso, que (adusto hijo de este Pirineo) su pecho inunda, o tarde, o mal o en vano, surcada de los dedos de su mano.

(Polifemo, VIII) 
Presenta Góngora sólo el cabello y la barba, donde la crespa fluidez del pelo llevaba espontáneamente a la metáfora marítima. Que tal no es una constante de su poesía puede verse a las claras con sólo observar que los retratos de Galatea, Glauco o Acis, seres acuáticos los tres, no incluyen en absoluto imágenes líquidas. Esto no quiere decir que el santafereño no imitara a Góngora de cerca. De sobra dicen su fidelidad al modelo sus soberbios bodegones (verdaderas emulaciones victoriosas), y tantas escenas bucólicas y piscatorias donde resplandece el subtexto de las Soledades. En Góngora se halla la metáfora acuática, pero esporádicamente, y en modo alguno con la obsesiva fuerza de un tropos fundamental. De hecho, en las ekphrasis de Domínguez Camargo sólo en una oportunidad se oye el eco de un subtexto gongorino. Se trata del retrato de un ángel que aparece en figura de gigante:

$$
\begin{aligned}
& \text { Mongibel centelloso la cimera } \\
& \text { en humosos torrentes escondido, } \\
& \text { en la tonsa oprimía cabellera } \\
& \text { un turbio Marañón, que dividido } \\
& \text { en torvas crines, en la frente austera } \\
& \text { y en el rostro escolloso descogido, } \\
& \text { en ondas anegó de austeridades } \\
& \text { fatal concurso de monstruosidades. }
\end{aligned}
$$

$$
\text { (V, cxvi) }
$$

El texto subyacente en estos versos es muy obvio: este Mongibel lo es porque Polifemo «un monte era de miembros eminentex. El resto bien puede ser una limitación transformadora del retrato del mostruoso gigante gongorino. Notemos de paso la coherencia en la imagen de Domínguez Camargo. Ya que se trata de un hombre-monte, las aguas corren por un «rostro escolloso», y así abre la octava siguiente con un ceñido resumen de la doble imagen que ha proyectado en su retrato:

Un peñasco de acero era el gigante de muchas olas negras inundado.

$$
\text { (V, cxvii) }
$$

La presencia de Góngora es aquí evidente: gigante-monte-negra cabellera torrentosa. La concatenación metafórica exige claramente el pretexto del Polifemo. Pero la elaboración poética, incluso en este caso, contiene tal riqueza que elude toda concepción de una imitatio sin consumada labor transformadora.

La descripción de la cara de San Ignacio renueva estas visiones de rostros oceánicos: 
Océano de luz su rostro era que en cosquillosa fúlgida mareta hervía, en cuyo seno negra fuera espuma, aun el fulgor de alto cometa; no fuera esquife la mayor esfera, no breve pez aun el mayor planeta: pues sin margen, sin ley, sus arreboles quiebran al aire piélagos de soles.

(III, xxi)

La excepcional fecundidad que Domínguez Camargo otorga a las metáforas marítimas parece inextinguible. El proceso mismo de conflactio se presta a la apoteosis, y la apoteosis de lo divino se vuelve en Camargo su epifanía. Todos estos retratos son descripción de realidades sagradas. Su obra maestra lo es también. En todo el Poema Heroico, y posiblemente en toda la literatura de la América virreinal, jamás se ha pintado un retrato más sorprendente que la ekphrasis que Domínguez Camargo hace de la Virgen. La descripción de la belleza femenina es uno de los tópicos por más tratados, más proclives al clisé, como lo demuestra y lo declara sin ambajes el fino humor de Sor Juana en sus ovillejos. La imaginería suntuaria que desde el Canzoniere inundó toda la lírica occidental es harto conocida. Lo notable en la poesía del santafereño es el empleo de motivos que el uso había vuelto lugares comunes para diluirlos en imágenes acuáticas que como ácidos, licúan las sólidas gemas petrarquistas y sus consabidas flores llevándolas a la sorpresa de un renovado y hasta nuevo esplendor denotativo. En el caso de la ekphrasis marial recordemos alguna Inmaculada de Murillo, su manto alzado por un viento invisible contra un aire de oro, toda rodeada de querubines y coronada de estrellas. Así la Virgen llega al recinto de Ignacio de Loyola:
Al aire el carro, y a la tierra, inunda
en piélagos de fúlgidas centellas, en cuyas ondas muchos querubines sin vestirse de escama son delfines.

Otra imaginación, más vulgarmente, hubiese visto en los ángeles, porque vuelan, aves o mariposas. Para nuestro poeta, ya que su cielo está hecho de ondas fúlgidas los querubes son peces. Con notable precisión alusiva los declara delfines, cuyas curvas retozantes han significado siempre amigo augurio de salvación (De hecho, después de contemplar la hermosura sin par de María, Ignacio hace voto de castidad perpetua. La divina Madre es el imán que vuelve al futuro santo verdadero secuaz del cielo, «a quien aclame la memoria / aguja de marear golfos de glo- 
ria» II, li). Entre las ondas de ese golfo se ve la belleza virginal, toda ella también en pura onda:

Nilo es de oro el cabello, al sol bruñido, o inunde el pecho, o ya la espalda esconda; en siete no, en cien venas dividido, cuando las cuenta el viento en onda y onda: suävemente un caracol torcido o las nada, la oreja, o ya las sonda, cuando de doce estrellas el armada o sonda sus orillas o las nada.

(II, xxxv)

Casi con las mismísimas palabras ya habiamos visto derramarse este Nilo del cabello sobre los hombros del crucificado. Pero aquí el poeta acumuló las imágenes de lo fluido y sinuoso, subrayándolas con la cuidadosa precisión de ese "en siete no, en cien venas», y esa cuenta «en onda y onda». Una retórica sabia ha multiplicado e individualizado la realidad acuática de esta cabellera que ya no es cabello de oro sino ríos, aguas doradas donde nada el caracol-oreja, mientras por sus orillas, y en el mar de luz que lo rodea, las estrellas que ritualmente coronan a la Inmaculada se ven como una flota de naves sondando sus multiplicadas aguas. Porque, si el Cielo es un mar, la Virgen es acabada visión marina:

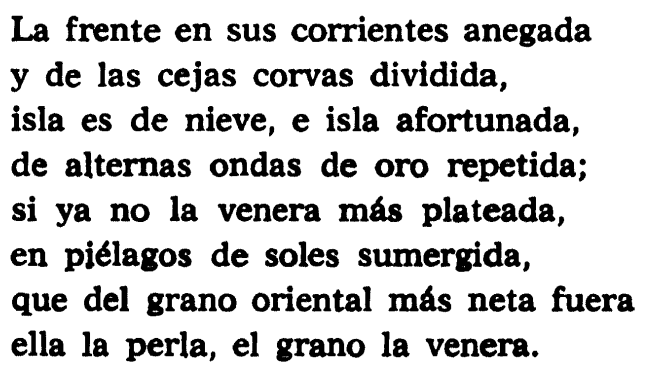

(xxxvi)

Imágenes de complejísima suntuosidad, pues porque la frente se explaya entre el Nilo del cabello es isla, por lo blanca, de nieve, así como de plata; por estar entre un mar de soles es venera y, por lo alba, perla, siendo entonces la frente de María perla, venera e isla a un tiempo. Es notable en estos versos la metamorfosis de los lugares más comunes. La piel de nieve, de plata o de perla ¿qué podía estar más manoseado y resultar más previsible? $Y$, sin embargo, esta frente-isla, con sus maravillosas connotaciones de aquellas legendarias Islas Afortunadas, esa frente-venera, símbolo por excelencia de la eterna Venus, hija de la espuma, la siempre marina Venus celestial; esa frente que siendo concha 
de la perla es la perla misma... todo esto no sólo es nuevo y bello. Es bello porque es profundo. Los tropos de nuestro poeta no son meramente suntuarios. Dice Eliade que la perla resume alos poderes de las aguas (concha) ${ }^{18}$. Sin duda en esta frente de María se alza el arquetipo de la Venus celeste, la Magna Mater, que es suma y origen de la vida, rodeada de delfines, símbolos de salvación y siempre símbolos de las aguas. La perla misma, hecha de luz y agua, tejida por los rayos de la luna ${ }^{19}$, anuncia la presencia lunar en la carne de María:

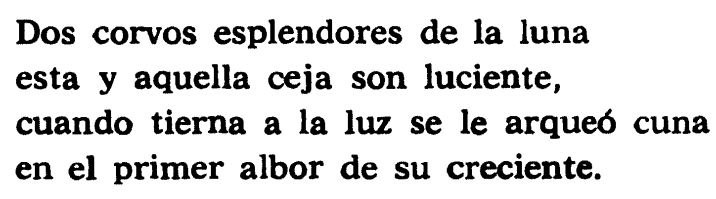

(xxxvii)

La estrecha unión entre lo lunar y lo acuático es sobradamente conocida: «y las aguas fluyen desde las fuentes de la luna» ${ }^{20}$. La luna es, claro está, otra epifanía de la Magna Mater, Madre de las Aguas. En los ojos de María se continúa la metáfora que ya vimos en las niñas-sirenas de Jesús (xxxviii). Entre las aguas de estos ojos nace el estrecho que separa los mares de las mejillas. Mares de leche, pero a la vez, mares rojos porque sonrosan azahares. Se ha hablado con propiedad de poesía simbiótica al estudiar la de Ronsard ${ }^{21}$. Hondamente simbiótica es, por cierto, la de Domínguez Camargo.

Fértil de leche y primavera, la carne de María es un piélago en flor. La metáfora floral se continúa en la descripción de la boca, que desde el lugar común del clavel nos lleva a otra revelación de maravillas:

Estrecho de marfil, entre los ojos la nariz se origina, a los dos mares que en leche están cuando ventilan rojos, ondas en las mejillas de azahares 22;

\footnotetext{
18 Patterns, pág. 156.

19 Ibidem.

20 En Langdon Epic, citado por Eliade, Patterns, pág. 159.

21 ANDRÉ GENDRE, Ronsard, poéte de la conquéte amoureuse (Neuchâtel, 1970), páginas 363-364.

22 Ver en Ronsard una imagen semejante: «Ces flotz jumeaulx de laict bien espoissi, / vont \& revont par leur blanche valée, / comme à son bord la marine salée / qui lente va, lente revient aussi.» Pierre Ronsard, Les Amours, ed. H. y C. Weber (París, 1963), pág. 118.
} 
Si desluce el clavel tizna la nieve purpúrea boca como blanco diente, que fuera de coral la cuna breve en que durmiera en perlas el oriente 23.

(xxxix-xl)

Estos cuatro versos que pintan la boca inmóvil, con su resolución en nuevas imágenes marinas, tienen una belleza pulida pero no asombrosa porque, al fin y al cabo, el coral de los labios y las perlas de los dientes no son hallazgos notables. Lo es sí la configuración de esa cuna de coral donde el sol reposa entre perlas, paisaje del mar oculto en la boca de la Virgen. Pero si los labios quietos son de admirar, cuando el poeta los hace mover nos dejan atónitos, tanto por lo inédito de la imagen cuanto por lo certero de su visión:

$$
\begin{aligned}
& \text { si, cuando a razonar dulce se mueve } \\
& \text { no fuera el labio rojo, suavemente, } \\
& \text { meandro breve de carmín adonde } \\
& \text { turba de cisnes cándidos se esconde. }
\end{aligned}
$$

En efecto, la curva del labio es como un meandro, y más si se mueve, pues a lo sinuoso se une el dinamismo de lo fluido. Por los labios, entreabiertos al hablar, asoman los dientes, por lo blancos -y por lo dulce del habla - cisnes, y cisnes por ser arroyos los labios que los esconden. La belleza del descubrimiento de Domínguez Camargo no se agota en su indudable originalidad. Lo que define la hermosura de su palabra poética es la coherencia y la justeza de estas imágenes.

Si es breve mar la boca por dormirse en ella el sol, breve mar es también el hoyuelo de su barbilla:

$$
\begin{aligned}
& \text { el sol como en su cuna se durmiera } \\
& \text { en el hoyuelo de su barba bella; } \\
& \text { y si hubiera una estrella que muriera, } \\
& \text { urna el hoyuelo fuera de la estrella. }
\end{aligned}
$$

Por fin la marítima belleza de María se cubre de azules mares, esos piélagos tejidos que en su barroco movimiento se curvan en golfos y se levantan en olas, para vestir el blanco cuerpo de la Virgen, o mejor esas

\footnotetext{
23 He aquí como Domínguez Camargo describe otra boca de mujer: «Oficina, la mar, su breve boca / consagrará del ámbar, cuyo aliento, / en diente y diente como en roca y roca, / por adobarse le inculcara el viento» (IV, ccxxxi).
} 
*rocas de marfil» que cubiertas de aguas y batidas por vientos celestiales esconden la augusta fertilidad de la Magna Mater:

Si excede esta beldad, hijo la fía
en sus brazos un Niño tan amante
que al cuello se eslabona de Maria;
hilado su cabello es un diamante,
su cuerpo de las carnes es del día
cuando aun en leche el sol es luz infant
Talar el manto de zafir tejido
cuanta beldad le cela, le ha inundado,
azul undoso piélago, tendido
donde, al soplo del aire combatido
en tormentosas rugas se ha alterado,
que entre las rocas de marfil ocultas
crestadas hondas son, crespas resultas.

(xlv-xlri)

La Magna Mater en una perfecta epifania, y con ella ese hijo solar que completa este arquetipo acabado de lo fecundo ${ }^{24}$. No veo yo como ha sido posible pensar que semejante visión de la Madre Sagrada se escribió «con el descuido inopinado alguna vez de quien arrebatado por la lírica olvida que está cantando a la Madre de Dios, para detenerse morosamente en su cuerpo soberano con un hálito inevitable de amor carnal» ${ }^{25}$. Que el poeta se detiene en el cuerpo de María es bien cierto, aunque lo hace mucho menos morosamente que el gran Arias Montano, cuyo clarísimo humanismo no sintió que fuera ningún atrevimiento escribir «de la hermosura exterior de Nuestra Señora», explayándose en las muchas bellezas de los senos y del mismísimo vientre de la Virgen ${ }^{26}$.

24 Sobre la Magna Mater y el hijo solar, ver C. G. JunG, Symbols of Transformation, 2.: ed. (Princeton, 1976), caps. IV y V.

25 Guillermo Hernández de Alba en su estudio preliminar a la edición de TorRBs Quintero, en Obras, pág. Ixxxviii.

26 «De la hermosura exterior de Nuestra Señora», donde ARIas Montano, tomando muchas imágenes del Cantar de los Cantares, describe los pechos de María: «qué diré de los pechos, / de leche milagrosa abastecidos? Semejantes son hechos / a los recién nacidos / cabritos, entre lilios mantenidos; / más frescos son y hermosos, / más blancos que el jazmín y armiño fino; / más dulces y sabrosos / que el esmerado vino, / y que el ambrosia, que es manjar divinox. Compárese esto con la estrofa xlv, en que Camargo alude a los senos de María, que se adivinan a través de la «túnica augusta, claramente obscura», y que son «dos cúpulas del templo de hermosura: / dos pomos por quien Ida el suyo enmiende; / dos Potosis de la beldad más pura, / donde en sus venas un cristal desata, / de quien es piedra el sol, y él es la plata». Como se ve, aunque Domínguez Camargo no recurre al Cantar de los Cantares, sus versos no son ni más ni menos eróticos que los de Arias Montano; nótese que ambos ponen claro acento en el producto de esos pe-

LXVI, 3.0-4.0. -8 
Claro es que ni en Arias Montano ni en Domínguez Camargo hay hálito alguno de amor carnal. Imágenes sensuales ¿cómo podría no haberlas? La hermosura de María encontró desde muy temprano el cauce estupendamente sensual de las imágenes del Cantar de los Cantares. La plástica barroca repitió, sin hálitos carnales de ninguna especie, las figuras de la Virgen de la leche, mostrando reverente los pechos que habían alimentado el milagro. En todo esto hay sensorialidad, pero no sexualidad. La poesía de Domínguez Camargo no tiene nada de ascético (salvo el tema ignaciano); tampoco tiene nada de profano. Por el contrario, el retrato de María es una apoteosis de la Magna Mater, en el cual la imaginación creadora ha sabido hallar los símbolos más perennes del arquetipo femenino, sagrado desde los orígenes del pensamiento religioso. Giovanni Meo Zilio es, sin duda, el crítico más agudo que ha tenido la poesía de Domínguez Camargo, quien en un breve lamparazo parece haber presentido el arquetipo eterno en esta ekphrasis de la Virgen, porque habla de su plenitud total, "reconducida a la etapa pagana, anterior al pudor de la humanidad "27. Claro que tampoco pienso yo que haya nada de pagano en la cuestión, porque el arquetipo de la Magna Mater es tan cristiano como pagano, por ser eterno en cuanto idea primigenia de lo sacro. De ahí que por una vez difiero de Meo Zilio que considera la plenitud de María dissacrata en los versos de nuestro poeta. Por el contrario, creo que justamente el recurrente uso de símbolos arquetípicos hace de esta imagen de María una realidad sacralizada por esencia, y por esencia epifánica. Respecto al pudor... éste es cosa que varía con mores y vestimentas. Nuestro siglo, tan poco pudoroso, llega hasta a tener vergüenza de los pechos lactantes de una madre, justamente porque ha sexualizado hasta negar su función básica los senos femeninos, hechos puro objeto de deseo y desvestidos de maternidad. Hasta no hace tanto tiempo una madre dando el pecho a su niño podía ser vista en público, porque nuestras impuras vergüenzas aún no la habían desnaturalizado. El pudor del Siglo de Oro des-

chos, la leche que alimentó al Niño Dios. Arias Montano además describe el mismísimo vientre de la Virgen, cosa que jamás hizo Domínguez Camargo, y tampoco debe leerse en sus versos erotismo alguno, porque son devota alusión a un vientre entre todos sagrado: «Pues, ¿qué diré, Señora, / de vuestro vientre puro? A vos me ofrezco... / Un vaso me parece / de marfil primamente fabricado, / cuyo precio engrandece / de perlas ser sembrado, / y de finos safiros rodeado. / Parece un trigo hermoso / cercado de mil flores muy amenas, / fértil, dulce, oloroso, / con frescas azucenas / que alrededor le cercan como almenas.» El poema de ARIAs Montano se puede leer en Fray Luis de León y la Escuela Salamantina, ed. Cristóbal Cuevas (Madrid, 1982), págs. 144148.

27 Mro Zilio, Estudio, pág. 187. 
cubría reverente los senos de la Virgen, porque reconocía en ellos una realidad eminentemente sagrada. El tropos fundamental de la poesía de Domínguez Camargo tiende poderosamente a la fusión de realidades en una realidad sincrética, y en ese sincretismo se alcanza la epifanía de lo numénico. Pocas veces se ha logrado revelación poética tan completa de la Madre de Dios, Madre del sol, cuna del sol, Magna Mater en cada detalle de su cuerpo marino, de sus vestiduras oceánicas. Hasta en el aire-mar que la rodea con sus querubes delfines y sus naves-estrellas, María, Stella Maris, es supremamente Señora de las Aguas.

Este retrato de la Virgen es a mi juicio la apoteosis de la poesía de Domínguez Camargo. No es de asombrarse que lo sea, pues es natural que en la Magna Mater un poeta con semejante intuición de la materia haya podido condensar, intensificándolos, los más altos logros de su imaginación.

Hasta aquí he tratado de señalar la existencia de una constante fundamental en la poesía de Domínguez Camargo. Ya hemos visto cómo el poeta, a quien le sobraban recursos metafóricos de todo tipo, confrontado a cualquier entidad revela una fortísima tendencia a resolverla -y a disolverla - en un universo líquido, de preferencia oceánico. No creo yo que lo hiciera adrede, pero tampoco creo que lo hizo por casualidad. Probablemente se trata de esas intuiciones profundas y a menudo inconscientes con que intentamos entender el mundo, y que por su misma hondura son fundamentalmente arquetípicas. Cuando cielo, tierra, luz, aire, telas, carne, lámparas, batallas, muros, armaduras, mesas, camas, templos y jardines pueden ser nombrados en las variantes de una misma sustancia, el poeta está revelando su intuición de la materia. Para Domínguez Camargo la materia prima del universo es el agua. Las oceánicas, las fluyentes, las informes, las ilimitadas aguas primordiales.

Tales de Mileto inauguró la filosofía occidental con una intuición semejante. La inteligencia mítica de un sinnúmero de pueblos ha visto en las aguas fons et origo de todas las cosas. Las aguas (es decir, toda sustancia líquida) simbolizan toda potencialidad; porque preceden todas las formas incluyen a cada forma, y las anulan, diluyéndolas: «la base de toda manifestación cósmica, el depósito de todas las semillas, la materia primigenia de donde todo viene y a donde todo regresará ${ }^{23}$. E] mundo de lo fluido, del que Fausto oyó la definición justa:

28 Eliade, Patterns, pág. 188. 
in Lebensfluten, im Tatensturm

Wall'ich auf und $\mathbf{a b}$,

Webe hin und her

Geburt und Grab,

Ein ewiges Meer,

Ein wechselnd Weben,

Ein glühend Leben 20 .

(en el fluir de la vida y de la acción la tormenta,

en mi ola voy y vengo

tejiendo en mi movimiento

mi tumba y mi nacimiento,

infinito mar eterno,

la trama de lo viviente,

sin cesar formas sin fin

que se mezclan relucientes).

La intuición de Domínguez Camargo, al hacer del agua la materia prima de su mundo poético, halló la inextinguible riqueza de un arquetipo que podía abarcarlo todo, infinitamente fértil, infinitamente proteico. Origen de toda vida, podía serlo de toda metamorfosis $y$, metáfora de toda realidad por ser la fuente de cada una de ellas. Así el arquetipo mismo parece haber germinado en el genio del poeta un mundo perpetuamente renovado en sus infinitas aguas primordiales.

\section{Alicia de Colombi-Monguio \\ State University of New York, Albany}

99 Goethes Werke, III, ed. Erich Trunz (Hamburgo, 1964), Faust, I, pág. 24. 